\title{
Issues covered in 'My 2 innings': A discussion from my personal perspective
}

\author{
P. R. Shankar \\ Department of Pharmacology, KIST Medical College, Lalitpur, Nepal.
}

Professor Dr. Hemang Dixit is a well known Nepalese academician and writer. The second edition of his autobiography has recently been published. Professor Dixit survived an attempt on his life on $4^{\text {th }}$ May 2006 and has titled his book 'My 2 innings'.

Professor Dixit talks about rote learning during his early school days in Kathmandu. Students learnt things by heart and often did not know about the meaning of what they learned. Rote learning is especially prevalent in South Asia and recently has come in for intense scrutiny. Medical education has been criticized as encouraging memorization and repetition of facts. Problem-based learning (PBL) a 'recent' development at least in our part of the world encourages students to bring together their knowledge of various subjects to solve a clinical problem. PBL both alone or in combination with other learning strategies is increasingly common in developed nations and is also being used in the developing world.

The second issue which echoes throughout the book is the dominance of the British Empire in world affairs. Britain ruled a large part of the world and Nepal though not a part of the empire was within its sphere of influence. The system of medical education in Nepal has been heavily influenced by the colonial one instituted by the British in SouthAsia. The language of instruction in medical schools and most other educational institutions continues to be English. Many Nepalese have served and continue to serve in the British and

Correspondences: Dr. P.R. Shankar

E-mail: ravi.dr.shankar@gmail.com other armies. An unfortunate point is that the system of medical education in many former colonies continues to be the one prevalent when these countries obtained independence from the British. The British have substantially revised their system in the ensuing years but not much has been done in the erstwhile colonies.

The medical education scenario in Nepal is relatively young and Institute of Medicine (IoM) the first medical school is less than 40 years old. This has both advantages and disadvantages. The advantage is that Nepal did not inherit much of the baggage associated with medical education in other countries. IoM started with an innovative and daring curriculum which aimed to produce doctors for the community. At present, Patan Academy of Health Sciences (PAHS) is about to admit its first batch of undergraduate medical (MBBS) students and is stressing production of doctors for rural and underserved areas of Nepal. In Pharmacology one good thing which happened was students do not have to perform animal experiments in Nepal. In India and other parts of South Asia animal experiments were inherited as a part of the colonial baggage. In many developed countries animal experiments have been removed and only simulated experiments are shown to students. The minus point is that all infrastructures had to be built up from scratch. Another difference in Nepal is that majority of medical schools are in the private sector.

Prof. Dixit talks about the 'monoculture' of humans in his book. Human beings have over the years become the dominant force on the planet. While the 
growth of the human race and its increasing prosperity is to be welcomed this has taken place sadly at the cost of other animals and plants. Many species have become extinct and today mankind is threatened with ecological destruction. Our planet earth is in grave danger. South Asia sadly has the largest concentration of humans on the planet and on flying over the land mass desertification is evident with the dominant color being a dirty brown.

In olden days students used to start school only around seven years of age. These days students start attending school very early - by around three years. I personally feel the early days of childhood are being destroyed by the proliferation of play schools, preschools and nurseries. Children should be free to enjoy life at least till six years of age. In many western countries even today school starts only around seven years of age. Putting too much burden on the child at a very early age can be detrimental. The author describes the journey to Kathmandu from the Indian plains in detail. The usual route is from Birgunj to Amlekhgunj to Bhimphedi, Khulekhani and then to Thankot. Recently a new road has been cut to Dakshinkali at the southern fringe of the valley. This route has again become important with Tata Sumo vehicles plying from Birgunj to Kathmandu through Hetauda, Bhimphedi and Khulekhani. Street vendors selling ices, cotton candy and kulfi are still common in the valley and other parts of Nepal as they were in the days of Prof. Dixit's childhood. The concern about hygiene of these preparations and of the quality of the water used still remains.

Dr. Dixit describes his schooling in Nainital and Shimla. Both schools were ardent believers of the maxim 'Spare the road and spoil the child' and corporal punishment was quite common. In recent times there has been vigorous debate about corporal punishment and its effect on the child's psyche and development and it has been banned in many countries. The author describes his classmates at Bishop Cotton School, Shimla in some detail. Afamous class mate was Ruskin Bond, the famous Anglo-Indian writer. A few years back he had visited Kathmandu during a book exhibition and had an emotional reunion with Prof. Dixit. The author describes his love of writing which developed at an early age and his early manuscripts and poems which were eventually published. $\mathrm{He}$ describes the travails of writers in Nepal. Writing in Nepal has always been a risky and precarious undertaking. Writers in English are in an even more precarious position as the audience for their works is limited. Prof. Dixit suggests that students of English literature be required to purchase and read books by recent Nepalese authors or writers living and working in Nepal. I agree with the author that this will give students a broader perspective, introduce them to contemporary writing and increase the market for writing in English.

The author describes how rare it was to have a car in the olden days and how cars were the preserve of the elite. Many other authors have described the process whereby cars were dismantled and transported by coolies over the hills, brought to the valley and then reassembled again. Today the valley is chock-a-block with cars, buses and other vehicles. In the early nineties air pollution caused by vehicles became a major problem and the Vikram tempos were banished from the Kathmandu valley. Old lorries are a major pollution source and I have often seen lumbering behemoths belching thick black smoke into the atmosphere. 
The young writer left Kathmandu to study in London. His description of the journey by air is interesting. He flew by a special plane carrying mainly cargo to Calcutta (now Kolkata) and from there to Karachi. From Karachi he went to Cairo and then over the Alps and across the English channel to London. There is no description of racism and racially motivated attacks. May be in the 1950s there were only few South Asians in the United Kingdom (UK). Unfortunately racial attacks have become more common not only in the UK but also in Australia and other places. The author describes his favorable impressions of his visit to Edinburgh. The quality of life and the peacefulness of the place impressed him greatly and he says it would be wonderful to live in Edinburgh and work in London. He goes on to state the same about Kathmandu and Pokhara. Having lived in both cities I must say Pokhara has a lot going for it in terms of peacefulness, cleanliness and quality of life but Kathmandu has the economic opportunities. Living in one and working in the other is like having the best of two worlds. He describes the great tradition of English writing and medical fiction and describes Richard Gordon famous for his 'Carry on doctor' series. I used to watch the movies made from the series previously and recently happened to read one of the books.

The contribution of Penguin in the form of cheap books to readers in Britain has been stressed. Penguin slowly spread to many English speaking countries and Penguin India has recently started publishing many Indian authors writing in English. Let us hope Penguin will start encouraging Nepalese writers in English also. Prof. Dixit describes a radio enthusiast who picked up a transmission of Radio Nepal in Finland and goes on to talk about HAMS. Amateur radio enthusiasts were quite common previously and during my college days we used to have an amateur radio club. HAMS used to play an important role in ensuring communication and coordinating relief efforts. One of my close friends was an amateur radio enthusiast and some of his enthusiasm rubbed off on me.

The introduction of oral rehydration salts (ORS) in the early seventies was a revolution in the field of public health. This simple invention of salt and sugar dissolved in water has saved millions of lives the world over. NaKS puriya was prepared by the pharmacist at Kanti Hospital (where the author worked) and is the forerunner of the various ORS preparations available today in the Nepalese market. The initial days of the Institute of Medicine make for interesting reading. The community-oriented curriculum and departure from conventional medical education at the institute had generated controversy and skepticism initially. It was only later that the curriculum gained acceptance. The point raised by a visitor from Tanzania about whether Nepal can really be considered as a poor country is thought provoking. Nepalese shops have a good deal of merchandise on offer and more and more shopping malls are being built in the major cities. The author states we in South Asia could be considered to be better off than the Africans. I was also intrigued by the comment that water from the tap was not fit for human consumption in Jakarta, Indonesia. In Kathmandu the rivers have been made into cesspools and sewers and drinking water is in short supply. In many areas water has to be supplied using tankers and processed, packaged drinking water purchased at high cost. 
P. R. Shankar, Issues covered in 'My 2 innings': A discussion from my personal perspective

The growth of private medical schools in Nepal, and medical education in this country will be interested the Nepal Medical Council and the Nepal Medical to read this delightful book.

Association are also described. Prof. Dixit covers an important and turbulent period of Nepalese history in an interesting and lucid manner. Someone had recently commented that there had been more changes during the last fifty years in Nepal than in the previous five hundred! All those interested in Nepal, health in Nepal 